\title{
Dynamic capabilities and organizational performance: The mediating role of innovation
}

\section{Steven S Zhou, ${ }^{\star}$ Abby J Zhou, ${ }^{\star}$ Junzheng Feng** and Shisong Jiang§}

\begin{abstract}
How firms' dynamic capabilities lead to their competitive advantage and improved firm performance has been a core issue and full of debates. In this research, we theorize that dynamic capabilities, which could be defined by three distinct dimensions (sensing capability, integration capability, and reconfiguration capability), facilitate different types of innovation that in turn improve firm performance. Based on a sample of 204 Chinese firms, results from partial least squares structural equation modeling analyses generally support our arguments despite some nuanced differences existing among different dimensions of dynamic capabilities. This study contributes to dynamic capabilities literature by reducing the scarcity of empirical research and by uncovering the mechanisms through which dynamic capabilities influence firm performance.
\end{abstract}

Keywords: dynamic capabilities, sensing capability, integration capability, reconfiguration capability, innovation

Received 7 July 2016. Accepted 13 March 2017

\section{INTRODUCTION}

Dnamic capabilities are of considerable theoretical and practical importance. In a seminal paper, Teece, Pisano, and Shuen (1997) defined dynamic capabilities as the firm's ability to integrate, build, and reconfigure internal and external competences to address rapidly changing environments. From a practical perspective, over the last three decades, the rapid rate of technology change, the shortened product life cycles, the process of globalization, and the blurring industry boundaries make the business environments increasingly dynamic. Company executives need dynamic capabilities to address the dynamic environments. From a theoretical perspective, dynamic capabilities have been one of the most significant and challenging questions within the strategy domain, and might well be viewed as the 'Holy Grail' of strategic management (Helfat \& Peteraf, 2009).

Whether and how firms' dynamic capabilities lead to their competitive advantage and improved firm performance has been a core issue in the discussion of scholars. Indeed, there has been a hot debate around this question (Barreto, 2010; Peteraf, Di Stefano, \& Verona, 2013). On one hand, early proposals in this area clearly assumed a direct impact of dynamic capabilities on firm performance (Teece, Pisano, \& Shuen, 1997). More recently, Teece (2007, 2014b) reiterated that the dynamic capabilities framework was created with an ambitious agenda to help scholars and practitioners

* Xi'an Jiaotong-Liverpool University, Suzhou, China

** Management School, HangZhou Dianzi University, Hangzhou, China

$\S$ School of Economics and Management, Wuhan University, Wuhan, China

Corresponding author: ssjiang@whu.edu.cn 
understand the foundations of firm-level competitive advantage. On the other hand, other scholars like Eisenhardt and Martin (2000) reckoned that dynamic capabilities do not necessarily lead to improved performance. In their view, competitive advantage and improved firm performance do not rely on dynamic capabilities themselves but on the resource configurations created by them. Similarly, Zott (2003) maintained that dynamic capabilities are not directly linked to firm performance. Still other scholars proposed that dynamic capabilities may hurt rather than improve firm performance if there is no need to use dynamic capabilities (Zahra, Sapienza, \& Davidsson, 2006), or if dynamic capabilities involve substantial opportunity cost (Winter, 2003).

The debate arises from that the mechanisms through which dynamic capabilities influence firm performance remain unclear. Prominent scholars argue that dynamic capabilities enable firms to match the resource base with changing environments (Teece, Pisano, \& Shuen, 1997), create market change (Eisenhardt \& Martin, 2000), and facilitate resource access and resource development (Stadler, Helfat, \& Verona, 2013). According to Schilke (2014: 179), 'the dynamic capabilities perspective has been criticized for ... its confounding discussion of the effect of dynamic capabilities.' What deteriorates the theoretical confusion is that dynamic capabilities studies 'mainly focus on theoretical development, and empirical research lagged' (Danneels, 2016: 2183). Empirical research for mediating mechanisms is more scarce. The only notable exception is Protogerou, Caloghirou, and Lioukas (2012), who propose and empirically test that a mediating model of dynamic capabilities improve firm performance through operational capabilities. Their study, however, appears tautological in the sense that dynamic capabilities are defined to govern the rate of change of operational capabilities (Winter, 2003). Other empirical work explores the contingent effect of dynamic capabilities and firm performance relationship (Danneels, 2012; Wilden, Gudergan, Nielsen, \& Lings, 2013; Schilke, 2014). But before establishing any contingent effects, it is critical to reach a clear understanding of the mechanism through which dynamic capabilities influence performance in the first place.

The objective of this paper is to resolve this debate by proposing and empirically testing a mediating mechanism between dynamic capabilities and firm performance. Theoretically, the extant literature suggests that dynamic capabilities cannot only adapt to but also shape the environment change (Eisenhardt \& Martin, 2000; Teece, 2007). As innovations have been widely considered as key engines for firms to adapt to and shape the environment in which these firms operate, we propose that innovations serve as a mediating mechanism between dynamic capabilities and firm performance. In line with Teece, Pisano, and Shuen (1997), Teece (2007) and a recent review of Barreto (2010), dynamic capabilities are defined by three distinct dimensions: sensing capability, integration capability, and reconfiguration capability. Empirically, we used a sample of 204 Chinese firms to test our proposed model. We chose a sample of Chinese firms because they have been operated under a dynamic environment characterized by constant institutional change (Tang \& Tang, 2012; Young, Tsai, Wang, Liu, \& Ahlstrom, 2014), various technology sources and emerging markets since the reform and opening policy. Partial least squares structural equation modeling (PLS-SEM) was employed to deal with our complex model and to test multiple equations simultaneously. Our findings suggest that despite some nuanced differences existing among different dimensions of dynamic capabilities, innovation, especially technological innovation activities, do serve as a mediating mechanism.

\section{THEORY AND HYPOTHESES DEVELOPMENT}

Dynamic capability plays an important role in an organization as it underscores the accumulation of capabilities embedded in a firm and it is directly associated with its financial performance (Hsu \& Wang, 2012). In terms of performance, firms in a dynamic environment need to develop new products to secure their competitive advantages (Blonigen \& Taylor, 2000). But exploiting these opportunities requires firms to be equipped with strong and patient dynamic capabilities as well as continuous innovation. 
Innovation has been defined as an application of knowledge to produce new knowledge (Drucker, 1993). There is an excessive literature about innovation and its categorization. Benner and Tushman (2003) classified innovations into two dimensions: the proximity to the current technological trajectory and to the existing market segment. Therefore, by reviewing the existing literature, our research distinguished two specific types of innovations, i.e. technological innovation and market innovation. The former type is mainly about innovations that use advanced technology and offer greater benefits to mainstream customers and the latter type of innovations are those that target emerging market segments (Zhou, Yim, \& Tse, 2005).

It has been widely agreed there is a direct and positive relationship between innovation and performance (e.g., Damanpour \& Evan, 1984; Damanpour, 1991). The critical role of innovation in driving superior organizational performance has been widely supported, and there is no shortage of literature that stresses its importance (Cho \& Pucik, 2005). While resources like innovative patent per se can bring great advantages to a firm, the firm also needs to come up with such patents consistently (Dutta, Narasimhan, \& Rajiv, 2005). Thus, the different innovation capabilities are critical for a firm and it needs to constantly deploy, mobilize, and integrate its resources and capabilities and align them dynamically to innovate and create its own competitive advantage (Liao, Kickul, \& Ma, 2009; Yam, Lo, Tang, \& Lau, 2011).

However, there is a lack of both theoretical frameworks and empirical studies on the mechanism through which firm employ their dynamic capabilities and enhance organizational performance (Wang $\&$ Ahmed, 2007). More specifically, the extant literature has not addressed the link between dynamic capability and the different types of innovation, and how different types of innovation may influence the organizational performance. It is suggested that dynamic capability needs to be examined in an integrated framework (Wang \& Ahmed, 2007), therefore, we theoretically propose and empirically test a model incorporating dynamic capabilities and the mechanisms of how it leads to financial performance via influencing innovations in firms.

\section{Sensing capability}

In environments of rapid technological change and high velocity market, it is hard to predict and discern the trajectories of future development. New information and new knowledge can create opportunities for innovation. Therefore, it is important for firms to constantly scan, search, and explore opportunities across technologies and markets. Those activities were defined as sensing capability by Teece (2007).

Sensing involves investment in research activity and the probing and reproving of technological possibilities. Previous studies have emphasized that research activity will increase firm's own knowledge and the relevant prior knowledge is critical for organizations to evaluate the new information (Cohen \& Levinthal, 1990; Todorova \& Durisin, 2007). It has been identified that externally available information and resources affect all innovation activities and development of a firm (Yam et al., 2011). External technology ideas and discoveries that fall beyond a firm's search zone might be possibly overlooked because the firm cannot easily comprehend them (Rosenkopf \& Nerkar, 2001). Following this line of reasoning, older firms or experienced firms are likely to have routinized search strategies to improve the organizational innovation (Nelson \& Winter, 1982; Rosenkopf \& Nerkar, 2001). Therefore, the stronger sensing capability of a firm could possibly lead to more technological innovations in the organization.

Sensing also covers understanding of the latent demand, the structural evolution of industries and markets, and the likely responses of suppliers and competitors. Therefore, when opportunities are first glimpsed, sensing capability could not only help firms to understand which technologies should be explored, but also provide the necessary foundation for them to figure out which market segments should be targeted (Teece, Pisano, \& Shuen, 1997). Companies which are better at 'sensing' in the 
market could have a better understanding of what customers want and echo their needs via marketing innovations, e.g. creating new distribution channels (Agarwal, Krishna Erramilli, \& Dev, 2003). Based on the aforementioned positive relationship between innovation and performance, we propose the following hypotheses:

Hypothesis 1a: Technological innovation mediates the relationship between opportunity sensing capability and financial performance.

Hypothesis 1b: Market innovation mediates the relationship between opportunity sensing capability and financial performance.

\section{Integration capability}

Integration capability has been identified as one of the three classes of managerial functions, i.e. integration, guided learning, and reconfiguration/transformation, which are relevant to dynamic capabilities (Teece, Pisano, \& Shuen, 1997). Coase (1937) pointed out that the most obvious cost of organizing production through the marker mechanism is that of discovering what the relevant prices are, and these transaction costs make it more efficient to organize an activity within the firm. Therefore, the Coasian view of the firms believes that a firm should minimize the internal transaction cost (Coase, 1937). Following this logic, centralized R\&D could generate innovations that have a larger and broader impact on subsequent technological evolution by reducing the internal transaction costs associated with R\&D coordination across units in the organization (Argyres \& Silverman, 2004). However, in order to keep flexibility and responsiveness, resources should be decentralized while the firm is growing. Therefore, structural complexity and the amount of organizational units will be increased. It leads to the increase of transactional cost across organizational units (Teece, 2007). The dynamic capability focuses more on the efficient and effective transfer of technology/information between and among the various organizational units of a firm. It is believed that resource integrating capability could help firms to connect separate organizational units because it can help easing potential contractual problems. Moreover, integration also opens pathways to learning, sharing of know-how, and expertise through transfer of technology and know-how within a firm (Teece, 2014a).

Integration capability does not only include internal coordination, i.e. the capability for extensive coordination between different specialized subunits within an organization, but also include the capacity to integrate external resources. For instance, typical external integration activities include integrating market and customer knowledge and integrating knowledge of emerging technologies (Iansiti \& Clark, 1994). To some extent, integration capability enables firms to transform and convert resources into innovative outputs (Dutta, Narasimhan, \& Rajiv, 2005). We expect that integration capability could both increase technological innovation and market innovation. In terms of technological innovation, external integration capability could help firms to adopt technology from different areas while internal integration capability could facilitate firms to share knowledge internally. When a firm enters a new technological niche, it can divert free resources toward integrating new technological knowledge with existing technological knowledge repositories to increase innovative output (Kotha, Zheng, \& George, 2011). Therefore, firms need to build logics for vertical integration, outsourcing, and R\&D strategies to integrate both internal and external resources (Prencipe, 1997). They also need to maintain a thorough understanding of the contracted out technologies to be able to integrate them into the system and 'control' their evolution over time (Prencipe, 1997). Through the effective integration of internal and external technological knowledge, a firm is more likely to incorporate the characteristics necessary for success into the new products (Marsh \& Stock, 2006).

On the other hand, both internal and external integration capability can help transferring market information across the organizational units. The resource integration capability is rooted in routines 
and mechanisms that allow the organization to forecast customer requirements. More importantly, it also involves mechanisms that enable organizational members to interpret current market information and to construct visions of the future market. With the integration capability, the vision could be translated into market innovation that fits with the future market expectations (Iansiti \& Clark, 1994). Based on the aforementioned positive relationship between innovation and performance, we propose the following hypotheses:

Hypothesis 2a: Technological innovation mediates the relationship between resource integrating capability and financial performance.

Hypothesis 2b: Market innovation mediates the relationship between resource integrating capability and financial performance.

\section{Reconfiguration capability}

In order to sustain profitable growth, it is important for a company to recombine and to reconfigure assets and organizational structures when markets and technologies change. Knowledge and resources may depreciate over time, and it may lead to the lack of cumulative benefits from prior experiences (Sampson, 2005). Reconfiguration capability does not only support firms to maintain evolutionary fitness but also provide the possibility for them to escape from unfavorable path dependencies when it is necessary (Teece, 2007). Reconfiguration capability includes activities in which firms engage when adding, redeploying, recombining, or divesting resources or business units (Karim \& Capron, 2016). Organizational reconfiguration capability facilitates continuous evolution and can also become a mechanism for firms to obtain novel resources and capture innovation benefits. We believe that organizational reconfiguration capability could enhance both technology innovation and market innovation. In terms of the technological innovation, the intra-organizational knowledge exchange could be stimulated and the existing tacit knowledge could be externalized and distributed in the company via redeploying human resources and restructuring business units (Nonaka, 1994). Galunic and Rodan (1998) have pointed out that knowledge tacitness and context specificity have important consequences on the likelihoods of innovation. It is also proved that the deployment of firm-specific knowledge requires specific settings. Employees who hold the key knowledge may be reluctant to make specialized human capital investments when they are deployed inappropriately (Wang, He, \& Mahoney, 2009). To some extent, older firms or firms with more experiences can develop and understand their technological domains and recognize optimal conditions for recombination (Zahra \& George, 2002; Kotha, Zheng, \& George, 2011). Therefore, reconfiguration activities could improve technology innovation.

Meanwhile, organizational reconfiguration capability could also influence market innovation. Chakrabarti, Vidal, and Mitchell (2011) argued that the development of institutional market environment strongly affects the ability of firms to reconfigure resources and businesses, as well as to benefit from such reconfigurations. For instance, growth reconfigurations may lead to lower transaction costs in well-developed markets, resulting in more benefits being derived. Koza, Tallman, and Ataay (2011) also illustrate an interesting case about how Renault comprehends and coordinates via using a series of reconfiguration methods such as internal development, mergers, and acquisitions, to approach the new market. Based on those studies, we assume reconfiguration capability could help company to adapt to different market environments and figure out the innovative marketing strategy. Based on the aforementioned positive relationship between innovation and performance, we propose the following hypotheses:

Hypothesis 3a: Technological innovation mediates the relationship between organizational reconfiguration capability and financial performance. 
Hypothesis 3b: Market innovation mediates the relationship between organizational reconfiguration capability and financial performance.

\section{METHODOLOGY}

\section{Measurement}

Most of our measurement scales were adopted from or developed based on the previous studies. In the following measurement details, unless specified otherwise, all of the variables were measured using 7-point Likert-type scales ranging from $1=$ 'strongly disagree' to $7=$ 'strongly agree.' In terms of dynamic capabilities, as Danneels (2016: 2175) most recently noted that 'as a relatively young area of strategic management research, the area of dynamic capabilities lacks generally accepted approaches to measure its key constructs. Measuring dynamic capabilities is challenging.' Consequently, we have searched literature extensively to identify relevant items, which could help to assure content validity. Specifically, we adopted and integrated the arguments of dynamic capacity (Teece, 2000, 2007), and measured three dimensions of sensing, integration, and reconfiguration. In terms of the measurement of sensing capability, we adopted and developed measurement items based on Teece $(2000,2007)$ and O'Reilly and Tushman (2008). The items include investment in research activities with the aim of probing technological possibilities, probing and reproving the existing or potential customer demand, closely observing competitors and suppliers' innovation activities, following the frontier research in science and technology, and identifying the industrial development trends through various mechanisms. We adopted and integrated concepts and ideas in previous studies (Cepeda \& Vera, 2007; Wang \& Ahmed, 2007) to measure integration capability. We used three items such as adopting different areas of technological knowledge, sharing new knowledge across the organization internally, and transferring industrial information or market information across the organization internally. The measurement items of reconfiguration were adopted from Prieto, Revilla, and Rodríguez-Prado (2009) and Teece (2007). The items include the flexibility to reconfigure organizational structures, the autonomy of decision-making power of organizational departments, proper redesign of the existing working process and procedures, proper redesign of the existing tasks and functions of organizational departments, proper reconfiguration of the internal and external networks and communication mechanism, and capability to dispose the outdated resource or knowledge.

We used five items to measure technological innovation (Utterback, 1986; Anderson \& Tushman, 1990; Subramaniam \& Youndt, 2005): adopting new knowledge or technology in the process of innovation, innovations that make your existing production processes or equipment outdated, innovations that fundamentally change your current products/services, innovations that make your existing expertise or knowledge in current products/services outdated, and innovations that make new products/services replacing the existing ones. Three items were used to measure market innovation (Zhou, Yim \& Tse, 2005): our product concept is difficult for existing customers to evaluate or understand, our product involves high switching costs for existing customer, and the use of our product requires a major learning effort by existing customers. We used five items to measure the financial performance of firms based on Dyer and Reeves (1995) and Zahra and Bogner (2000): high ROI (return on investment), high ROA (return on assets), high increase rate of sales, high rate of sales profit, and high market share.

Following Schilke (2014), we controlled for firm size, firm age, and industry effects. Firm size, assessed by a firm's number of employees, can impact innovation activities (Schumpeter, 1942) and improve firm performance through economies of scale or scope (Qian, Wang, Geng, \& Yu, 2016). Firm age, measured as the number of years since the establishment of the firm, has been suggested to influence a firm's performance as well as innovation activities (Qian et al., 2016). The importance of the industry in which a firm competes as a predictor of firm-level variables is widely recognized in the 
literature (Dess, Ireland, \& Hitt, 1990). Industry was measured with a dummy variable (1 = 'high technology industry,' 0 = 'non-high technology industry'). In addition, in keeping with the Chinese context, we also controlled for ownership and location. Ownership has been shown to affect innovation (Choi, Lee, \& Williams, 2011) and performance (Tan, 2002), coded 1 if the firm is private firm and 0 otherwise. We coded location as 1 if the firm was located in the coastal regions, which created more munificent environments for businesses (Xu, Lu, \& Gu, 2014), and 0 otherwise.

\section{Data collection}

China is an active player in the global economy and it was chosen as the empirical setting of this study. The development of dynamic capabilities could be contingent on the dynamics of the environment (Day \& Wensley, 1988). However, limited research has included such contingencies in emerging economies (Kirca, Jayachandran, \& Bearden, 2005). China offers a rich context to test dynamic capability because its complex, fast-changing nature makes it critical for firms to survive and prosper in this country (Zhou \& $\mathrm{Li}, 2012)$. In other words, it is essential for Chinese firms to develop their dynamic capability to achieve and sustain superior performance over time in the changing business environment with economic transformation and upgrading, expansion of domestic consumption, growing of international markets, and advancement of the new type of industrialization. The infusion of new information from the emerging market in China also encourages companies to generate new ideas for innovations (Laursen \& Salter, 2006). The Chinese firms need to integrate knowledge from the potential markets in China, detect market trends, and invest accordingly to explore them (Zhou \& Li, 2012). Furthermore, the dramatic technological progress in China also requires companies to strongly pursue dynamic capacity to adapt to the environment with quick development of innovation, multiple sources of innovation, and different types of technological innovation (Zhang, Li, Li, \& Zhou, 2010). Therefore, the rapid changing and competitive business and technological environment makes China an appropriate context for testing firm's dynamic capability empirically. As the world's largest emerging economy, China shares many characteristics and similarities with other emerging economies (Peng, 2003). This makes China an appropriate representative context of emerging economies and therefore findings from this research could provide implications for firms operating in other emerging economies.

We used standard questionnaires to collect data for this research. Once a draft questionnaire was developed, we got feedback from several academic and managerial experts. Feedback from these experts was then taken and integrated into the final version of the questionnaire. The original questionnaire was developed in English and we translated it into Chinese via using a typical careful translation/back translation process to ensure accuracy and consistency (Beaton, Bombardier, Guillemin, \& Ferraz, 2000). Several Chinese researchers and managers were invited to check whether the Chinese version of questionnaire was totally clear. Based on their feedback, a few minor changes were applied to increase clarity.

We collected data from companies that are randomly located in different areas and cities in China with the help of local government bureaus and business service centers. The survey was conducted between June and September of 2011. We aimed to collect data from a variety of industries, therefore, our data covered different industries such as telecommunication, electronics, automobile, pharmaceuticals, manufacturing, logistic, and software. In addition, we planned to collect data from different types of organizations. Hence, the questionnaires were equally distributed among stated-owned enterprises, foreign-owned companies, joint ventures, and private firms. We contacted more than 1,000 companies in total and we collected 231 questionnaires. Among these, 27 incomplete questionnaires or questionnaires with high missing data rate were removed from the data set. Finally, we obtained questionnaires from 204 companies with two respondents from each company. One respondent holds a position of managing director/chief executive officer (CEO) and the other holds position of either R\&D or marketing manager. 
We followed several approaches to avoid the problem of common method bias. First, using a single survey respondent as the source for both the independent and dependent data may cause the possibility of common method bias (Podsakoff, MacKenzie, Lee, \& Podsakoff, 2003; Chang, Van Witteloostuijn, $\&$ Eden, 2010). Thus, in this research, we obtained data for independent and dependent measures from separate sources to avoid problems of self-report bias, consistency effect, and illusory correlations (Podsakoff et al., 2003). Specifically, we asked two respondents from each company to participate in the survey. The data of control and dependent variables came from one respondent, and the data of independent variables came from another respondent in the company. Second, we also conveyed to respondents that the purpose of this survey is only for academic research, and there is no 'right' or 'wrong' answers for the questions. Thus, the respondents' apprehension over their responses could be reduced and they would not give what they perceive as the best answers. Third, we also told the respondents that their personal information and answers would be fully confidential and anonymous, therefore, they would be more aligned with the research goal. Finally, we conducted Harman singlefactor test (Podsakoff \& Organ, 1986) by loading all the measures into an exploratory factor analysis with the assumption that the presence of CMV is indicated by the emergence of either a single factor or a general factor accounting for the majority of covariance among measures (Podsakoff et al., 2003). In our model, the variance of a single factor was $14.25 \%$, therefore, the majority of the variance could not be explained by a single factor and we assumed this research does not have a problem of CMV.

\section{Data analysis}

We used PLS-SEM as our multivariate statistical technique that allowed us to analyze multiple variables and multiple equations simultaneously. It has been popularly used in articles in top-tier journals. The estimation procedure of PLS is an ordinary least squares regression-based method rather than minimizing the error terms of the endogenous constructs to estimate the path relationships in the model (Hair, Ringle, \& Sarstedt, 2011, 2013). PLS works efficiently with complex model and small sample size, and it does not make assumptions about the underlying data. In contrast to covariancebased SEM, which needs a minimum sample size of 200 or often more (Marsh, Hau, Balla, \& Grayson, 1998), PLS is more appropriate for studies with relatively small samples or multiple indicators per latent variable (Birkinshaw, Morrison, \& Hulland, 1995; Hair, Ringle, \& Sarstedt, 2013). All of the constructs in this study had multiple indicators and an advantage of PLS is that it could weight indicator loadings on a construct in the context of the theoretical model rather than in isolation (Hulland, 1999; Hair, Ringle, \& Sarstedt, 2013).

The results of data analysis can be presented in two steps. First, in order to ensure the measurement validity and reliability of our theoretical framework, criteria on internal consistency, indicator reliability, convergent validity, and discriminant validity have been evaluated for our constructs. In terms of internal consistency, all of the composite reliability values and Cronbach's $\alpha$ values were $>0.8$ (see Table 2 ). We also achieved good indicator reliability as all of the indicator loadings were $>0.7$, and most of them were $>0.8$. In terms of convergent validity, all AVE (average variance extracted) scores were $>0.6$ (see Table 2). All constructs have a good discriminant validity as the indicators' outer loadings on their own constructs were all higher than all their cross loadings with other constructs. The square root of the AVE of each construct was higher than its highest correlation with any other construct in the model, and this also established discriminant validity (Fornell \& Larcker, 1981). The correlations are presented in Table 1.

Second, to evaluate the structural model of our theoretical framework, we examined construct collinearity, the coefficient of determination $\left(R^{2}\right)$, the significance of path coefficients, and direct and mediation effects (Hair, Ringle, \& Sarstedt, 2013; Hair, Sarstedt, Hopkins, \& Kuppelwieser, 2014). All of the $R^{2}$ scores were above 0.1 , the $R^{2}$ score for the final dependent variable (financial performance) was 0.28 . In addition, the tested model has been expanded to examine construct collinearity and the results were 
Table 1. Latent Variable correlation from partial least souares

\begin{tabular}{|c|c|c|c|c|c|c|c|c|c|c|c|}
\hline Company age & 1.000 & & & & & & & & & & \\
\hline Industry & 0.156 & 0.077 & 1.000 & & & & & & & & \\
\hline Company size & 0.453 & -0.007 & 0.381 & 1.000 & & & & & & & \\
\hline Integration & -0.113 & 0.408 & 0.004 & -0.098 & 1.000 & & & & & & \\
\hline Location & -0.264 & 0.108 & -0.203 & -0.387 & 0.072 & 1.000 & & & & & \\
\hline Reconfiguration & -0.130 & 0.376 & 0.053 & -0.171 & 0.720 & 0.111 & 0.308 & -0.118 & 1.000 & & \\
\hline Sensing & 0.054 & 0.452 & 0.091 & 0.125 & 0.698 & 0.046 & 0.185 & 0.020 & 0.526 & 1.000 & \\
\hline $\begin{array}{l}\text { Technological } \\
\text { innovation }\end{array}$ & -0.091 & 0.470 & 0.025 & -0.097 & 0.455 & 0.179 & 0.548 & -0.158 & 0.554 & 0.464 & 1.000 \\
\hline
\end{tabular}

$\mathrm{AVE}=$ average variance extracted. 


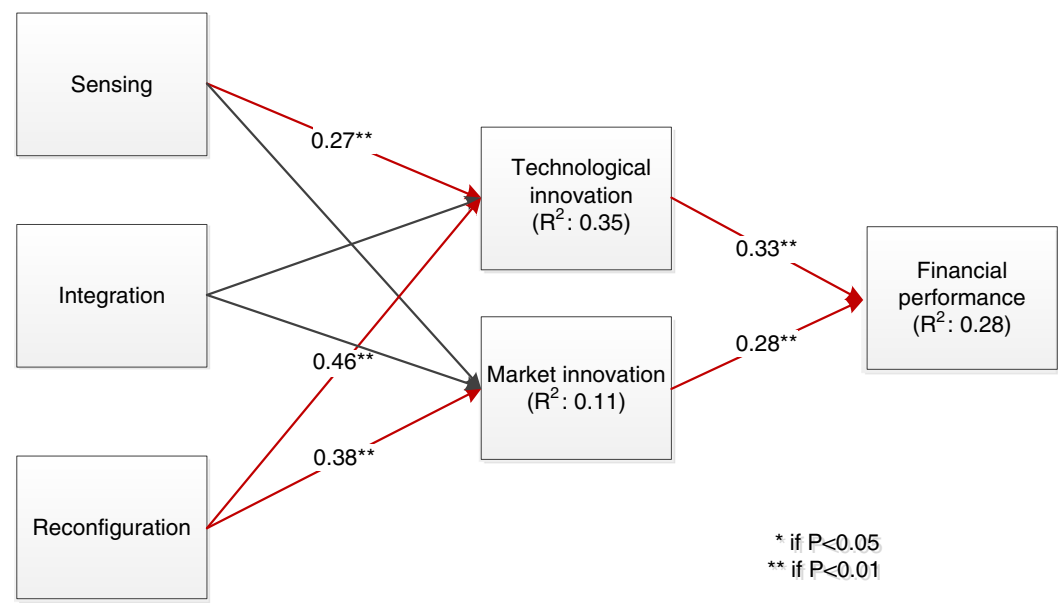

Figure 1. THEORETICAL FRAMEWORK AND RESULTS

excellent (all of the variance inflation factor (VIF) values were far below 5) which further shows that multicollinearity is not an issue for our model/data (Hair, Ringle, \& Sarstedt, 2013). Significance of path coefficients was calculated by using a bootstrapping algorithm with 5,000 subsamples for two-tailed test. The numbers and significance of path coefficients can be seen in Figure 1.

\section{RESULTS}

In terms of the mediation effects in this model, we examined six flow paths: (1) from sensing capability to technological innovation and then company performance, (2) from sensing capability to market innovation and then company performance, (3) from integration capability to technological innovation and then company performance, (4) from integration capability to market innovation and then company performance, (5) from reconfiguration capability to technological innovation and then company performance, and (6) from reconfiguration capability to market innovation and then company performance. We first tested the direct effects between three dimensions of dynamic capability and company performance, respectively. The direct relationships between two dimensions (sensing and reconfiguration) and company performance were significant. The direct relationship between integration and performance was not significant. We then calculated the variance accounted for scores by following the approaches of Hair, Ringle, and Sarstedt (2013). Three paths such as from sensing to technological innovation and then company performance, from reconfiguration to technological innovation and then company performance, and from reconfiguration to market innovation and then company performance showed significant mediation effects, whereas no mediation effect was observed for others. The variance accounted for scores for these three paths with significant mediation effects were $0.25,0.83$, and 0.78 , respectively. The results indicated that the relationship between sensing and company performance was partially mediated by technological innovation. The relationship between reconfiguration and company performance could be fully mediated by technological innovation and partially mediated by market innovation. These two effects were indirect-only mediation effects because the direct relationship between reconfiguration and company performance was not significant (Zhao, Lynch, \& Chen, 2010). This suggested that the path from reconfiguration to company performance can only work via the mediation effects of technological and market innovation, respectively. Therefore, $\mathrm{H} 1 \mathrm{a}, \mathrm{H} 3 \mathrm{a}$, and $\mathrm{H} 3 \mathrm{~b}$ were supported while $\mathrm{H} 1 \mathrm{~b}, \mathrm{H} 2 \mathrm{a}$, and $\mathrm{H} 2 \mathrm{~b}$ were rejected in this study. The detailed mediation results can be seen in Table 2. 
Table 2. Data results

\begin{tabular}{|c|c|c|c|c|}
\hline Constructs & Composite reliability & Cronbach's $\alpha$ & AVE & $R^{2}$ \\
\hline Integration & 0.91 & 0.85 & 0.77 & / \\
\hline Sensing & 0.91 & 0.88 & 0.67 & / \\
\hline Reconfiguration & 0.93 & 0.90 & 0.67 & / \\
\hline Market innovation & 0.91 & 0.85 & 0.77 & 0.11 \\
\hline Technological innovation & 0.89 & 0.84 & 0.61 & 0.35 \\
\hline Financial performance & 0.93 & 0.90 & 0.72 & 0.28 \\
\hline
\end{tabular}

$\mathrm{AVE}=$ average variance extracted.

Table 3. Mediation effects

\begin{tabular}{|c|c|c|c|c|c|c|}
\hline Path & Mediator & Direct effect & First path & $\begin{array}{l}\text { Second } \\
\text { path }\end{array}$ & VAF & Mediation \\
\hline $\begin{array}{l}\text { From sensing to technological } \\
\text { innovation and then to company } \\
\text { performance }\end{array}$ & $\begin{array}{l}\text { Technological } \\
\text { innovation }\end{array}$ & $0.26^{\star \star}$ & $0.27^{\star \star}$ & $0.33^{\star \star}$ & 0.25 & $\begin{array}{l}\text { Partial } \\
\text { mediation }\end{array}$ \\
\hline $\begin{array}{l}\text { From sensing to market innovation and } \\
\text { then to company performance }\end{array}$ & $\begin{array}{l}\text { Market } \\
\text { innovation }\end{array}$ & $0.26^{\star \star}$ & Not significant & $0.28 * \star$ & & \\
\hline $\begin{array}{l}\text { From integration to technological } \\
\text { innovation and then to company } \\
\text { performance }\end{array}$ & $\begin{array}{l}\text { Technological } \\
\text { innovation }\end{array}$ & $0.15^{+}$ & Not significant & $0.33^{\star \star}$ & & \\
\hline $\begin{array}{l}\text { From integration to market innovation } \\
\text { and then to company performance }\end{array}$ & $\begin{array}{l}\text { Market } \\
\text { innovation }\end{array}$ & $0.15^{+}$ & Not significant & $0.28^{\star \star}$ & & \\
\hline $\begin{array}{l}\text { From reconfiguration to technological } \\
\text { innovation and then to company } \\
\text { performance }\end{array}$ & $\begin{array}{c}\text { Technological } \\
\text { innovation }\end{array}$ & Not significant & $0.46^{\star \star}$ & $0.33^{\star \star}$ & 0.83 & $\begin{array}{l}\text { Indirect- } \\
\text { only full } \\
\text { mediation }\end{array}$ \\
\hline $\begin{array}{l}\text { From reconfiguration to market } \\
\text { innovation and then to company } \\
\text { performance }\end{array}$ & $\begin{array}{l}\text { Market } \\
\text { innovation }\end{array}$ & Not significant & $0.38^{\star \star}$ & $0.28^{\star \star}$ & 0.78 & $\begin{array}{l}\text { Indirect- } \\
\text { only } \\
\text { mediation }\end{array}$ \\
\hline
\end{tabular}

${ }^{+} P<0.1,{ }^{\star} P<0.05,{ }^{*} P<0.01$.

None of the control variables showed significance. Considering the specific context of China, we also have concern about the potential effect of government relations or connections on the development of dynamic capability in firms in China. We did a robust check by removing the data of state-owned enterprises, and the results were consistent (Table 3).

\section{DISCUSSION AND CONCLUSION}

Overall, this study helps reduce ambiguities regarding the mediating mechanism through which dynamic capabilities improve firm performance. Specifically, our findings provide some evidences suggesting that innovation, especially technological innovation, serves as an important mediating mechanism between dynamic capabilities and firm performance. Yet, there are two findings that deserve more discussions. First, one of the dimensions of dynamic capabilities, integration capability, has no significant impact on both types of innovation. The reason underlying this may be that in contrast to the other two dimensions, integration capability is 'a static concept' (Teece, Pisano, \& Shuen, 1997: 518) pertaining to linking and combining existing activities and resources. It is more 
related to integration of different activities with a purpose of encouraging efficiency, such as effective integration and standardization of business processes, and systematic implementation of business planning (Protogerou, Caloghirou, \& Lioukas, 2012), which is less likely to affect innovation activities (Abemathy, 1978; Benner \& Tushman, 2003).

Second and more subtle, while sensing capability has significant impact on technological innovation, it does not affect market innovation. The reason behind this may be that the executives tend to use brilliant improvisation (Winter, 2003) and simple rules (Bingham \& Eisenhardt, 2011) rather than sensing routines to facilitate market innovation because it is more fluid than technological innovation (Zhou, Yim, $\&$ Tse, 2005). For example, because market innovation is designed for new or emerging markets, it requires more creative improvisation. In contrast, technological innovation addresses the needs of existing markets, while adopting new and advanced technologies requires more routinized sensing activities.

\section{Theoretical and managerial implications}

This article makes several contributions to the dynamic capabilities literature. First, we provide a more nuanced understanding about the effects of dynamic capabilities on firm performance by empirically enhancing the arguments that the impacts of various dimensions of dynamic capabilities are not identical, which also helps to overcome the criticism of dynamic capabilities for being tautological (Barreto, 2010). Our research provides empirical support for the notion that different dimensions 'describe significantly different dynamic capability process categories' (Wilden et al., 2013: 79), and that they do not only necessarily covary with each other, but also with different consequences (Barreto, 2010; Wilden et al., 2013). Rather than treat dynamic capabilities as a whole, we decompose dynamic capabilities into three dimensions and examine the effects of each dimension. Our findings suggest that unlike sensing capability and reconfiguration capability, integration capability does not have positive impact on innovation activities. We thus provide a more nuanced understanding about the effects of dynamic capabilities and thus is more appropriate than that of Protogerou, Caloghirou, and Lioukas (2012), which limited dynamic capabilities to only those cases where high levels of all dimensions are evident. The distinct effect of the three dimensions of dynamic capabilities demonstrated in this study can also address the tautology problem of the concept of dynamic capabilities in that different dimensions of dynamic capabilities are linked to firm performance in different way.

Second, this article proposes and empirically validates innovation activities as mechanisms through which dynamic capabilities influence firm performance. The question of whether and how dynamic capabilities affect performance is still open and remain a source of debates (Helfat et al., 2009; Schilke, 2014). To reconcile these debates, we need a thorough understanding of the associated mediating mechanisms, which help us better understand how and why dynamic capabilities improve firm performance. This approach is also consistent with an 'indirect link' approach which has been considered as the most promising one (Barreto, 2010). Our study is a direct response to Barreto's (2010: 275-276) call for future research that 'should continue to explore these relationships between dynamic capabilities and intermediate outcomes, on one hand, and between intermediate outcomes and performance, on the other hand, to better assess which dynamic capabilities and intermediate outcomes deserve more attention.' Our findings enable us to conclude that dynamic capabilities could influence firm performance through innovation activities, especially technological innovation, despite some subtle differences existing among various dimensions of dynamic capabilities. Only after we have a clear understanding of the mediating mechanisms of dynamic capabilities effects can we explore further its boundary conditions by testing a set of moderating effects.

Third, this article contributes to reducing the relative scarcity of empirical research on the performance implications of dynamic capabilities, particularly on the mediating mechanisms of dynamic capabilities effects. This is important because the debate about dynamic capabilities has reached a 
point where theoretical arguments should be further complemented by relevant empirical work' (Protogerou, Caloghirou, \& Lioukas, 2012: 616). Without empirical studies, scholars may be trapped by endless arguing and debating with each other, and therefore research on dynamic capabilities would not progress as much as it could do.

In terms of managerial implications, our results provide guidance for managers on how to build and leverage dynamic capabilities, which has been a too vague and elusive concept (Kraatz \& Zajac, 2001) for managers to execute, in order to improve firm performance. First, given that our findings demonstrate that one of the three dimensions of dynamic capabilities: integration capability, does not have significant effects on two types of innovation, managers should place more emphasis on reconfiguration capability and sensing capability instead of integration capability. For example, managers need to pay special attention to industry trend and adopt best practice, however, the coordination and integration of activities inside the firm is not as important. Such suggestions may point to the importance of a loosely coupled structure within the firm.

Second, dynamic capabilities must be leveraged in aid of a good strategy to be effective (Teece, 2014b). Given that our findings which demonstrate that technological innovation activities serve as a significant mediating mechanism between dynamic capabilities and firm performance, the key for a good strategy is to use dynamic capabilities to facilitate innovation activities, especially technological innovation activities. Dynamic capabilities can serve a variety of purposes, including the creation, extension, and modification of resources (Stadler, Helfat, \& Verona, 2013). Focusing on innovation purpose could be effective as our findings suggest that innovation, especially technological innovation, should be present for superior performance achievement. For example, managers should allocate more resources to technological innovation activities rather than other domains, particularly when they face a situation of very limited resources. This suggestion is a reflection of the fact that bottleneck of the Chinese firms is technological innovation instead of market innovation, which needs to be overcome using dynamic capabilities.

\section{Limitations and future research}

Our study has some limitations that offer avenues for further research. First, our data are cross-sectional in nature which does not allow us to examine the influence of dynamic capabilities on innovation activities and firm performance over time and therefore could not definitively establish causality. Second, we assume a dynamic environment as a condition under which dynamic capabilities are relevant to improve firm performance. However, scholars (e.g., Eisenhardt \& Martin, 2000) also contend that dynamic capabilities may prove less effective in highly dynamic environments.

Therefore, a potential extension of this research would be to employ a longitudinal study design to empirically confirm causality and assess innovation and firm performance outcomes over time. Future research could also examine the roles of environment dynamism in the relationship among dynamic capabilities, innovation activities, and firm performance. Besides, despite the positive effect of dynamic capabilities on innovation activities and firm performance, building and maintaining dynamic capabilities involves substantial cost, which should be explicitly taken into account in future research. Finally, dynamic capabilities may reside in large measure with the enterprise's top management team (Teece, 2007), which is also termed dynamic managerial capabilities (Helfat and Martin, 2015), therefore, it might also be interesting to conduct multilevel research in the future, which provides a means to explore the micro-foundations of dynamic capabilities.

\section{Conclusion}

In conclusion, our empirical research helps clarify how dynamic capabilities improve firm performance. Generally, despite somewhat nuanced differential impacts of various dimensions of dynamic 
capabilities, the findings presented here suggest that innovation, especially technological innovation activities, play a mediating mechanism. We hope this will spur further empirical studies and therefore advance the dynamic capabilities research which has been viewed as the 'Holy Grail' of strategic management.

\section{ACKNOWLEDGEMENTS}

This research is supported by National Natural Science Foundation of China (project number: 71572131, 71202122, and 71302094).

This manuscript is an original work that has not been submitted to nor published anywhere else. All authors have read and approved the paper and have met the criteria for authorship.

Previous studies on the performance implications of dynamic capabilities have been full of debates. This study contributes to dynamic capabilities literature by uncovering the mechanisms through which dynamic capabilities influence firm performance and by reducing the scarcity of empirical research. Our unique research setting with a sample of 204 Chinese firms aligns with JMO's 'global focus' and its value of diversity. Our results can provide implications and guidance for managers on how to build and leverage dynamic capabilities in order to improve firm performance.

\section{References}

Abemathy, W. (1978). The productivity dilemma. Baltimore, MD: Johns Hopkins University Press.

Agarwal, S., Krishna Erramilli, M., \& Dev, C. S. (2003). Market orientation and performance in service firms: Role of innovation. Journal of Services Marketing, 17(1), 68-82.

Anderson, P., \& Tushman, M. L. (1990). Technological discontinuities and dominant designs: A cyclical model of technological change. Administrative Science Quarterly, 35(4), 604-633.

Argyres, N. S., \& Silverman, B. S. (2004). R\&D, organization structure, and the development of corporate technological knowledge. Strategic Management Journal, 25(8-9), 929-958.

Barreto, I. (2010). Dynamic capabilities: A review of past research and an agenda for the future. Journal of Management, 36(1), 256-280.

Beaton, D. E., Bombardier, C., Guillemin, F., \& Ferraz, M. B. (2000). Guidelines for the process of cross-cultural adaptation of self-report measures. Spine, 25(24), 3186-3191.

Benner, M. J., \& Tushman, M. L. (2003). Exploitation, exploration, and process management: The productivity dilemma revisited. Academy of Management Review, 28(2), 238-256.

Bingham, C. B., \& Eisenhardt, K. M. (2011). Rational heuristics: The 'simple rules' that strategists learn from process experience. Strategic Management Journal, 32(13), 1437-1464.

Birkinshaw, J., Morrison, A., \& Hulland, J. (1995). Structural and competitive determinants of a global integration strategy. Strategic Management Journal, 16(8), 637-655.

Blonigen, B. A., \& Taylor, C. T. (2000). R\&D intensity and acquisitions in high-technology industries: Evidence from the US electronic and electrical equipment industries. Journal of Industrial Economics, 48(1), 47-70.

Cepeda, G., \& Vera, D. (2007). Dynamic capabilities and operational capabilities: A knowledge management perspective. Journal of Business Research, 60(5), 426-437.

Chakrabarti, A., Vidal, E., \& Mitchell, W. (2011). Business transformation in heterogeneous environments: The impact of market development and firm strength on retrenchment and growth reconfiguration. Global Strategy Journal, 1(1-2), 6-26.

Chang, S.-J., Van Witteloostuijn, A., \& Eden, L. (2010). From the editors: Common method variance in international business research. Journal of International Business Studies, 41(2), 178-184.

Cho, H. J., \& Pucik, V. (2005). Relationship between innovativeness, quality, growth, profitability, and market value. Strategic Management Journal, 26(6), 555-575.

Choi, S. B., Lee, S. H., \& Williams, C. (2011). Ownership and firm innovation in a transition economy: Evidence from China. Research Policy, 40(3), 441-452. 
Coase, R. H. (1937). The nature of the firm. Economica, 4(16), 386-405.

Cohen, W. M., \& Levinthal, D. A. (1990). Absorptive capacity: A new perspective on learning and innovation. Administrative Science Quarterly, 35(1), 128-152.

Damanpour, F. (1991). Organizational innovation: A meta-analysis of effects of determinants and moderators. Academy of Management Journal, 34(3), 555-590.

Damanpour, F., \& Evan, W. M. (1984). Organizational innovation and performance: The problem of 'organizational lag'. Administrative Science Quarterly, 29(3), 392-409.

Danneels, E. (2012). Second-order competences and schumpeterian rents. Strategic Entrepreneurship Journal, 6(1), 42-58.

Danneels, E. (2016). Survey measures of first- and second-order competences. Strategic Management Journal, 37(10), 2174-2188.

Day, G. S., \& Wensley, R. (1988). Assessing advantage: A framework for diagnosing competitive superiority. Journal of Marketing, 52(2), 1-20.

Dess, G. G., Ireland, R. D., \& Hitt, M. A. (1990). Industry effects and strategic management research. Journal of Management, 16(1), 7-27.

Drucker, P. F. (1993). Concept of the corporation. New York: Transaction.

Dutta, S., Narasimhan, O., \& Rajiv, S. (2005). Conceptualizing and measuring capabilities: Methodology and empirical application. Strategic Management Journal, 26(3), 277-285.

Dyer, L., \& Reeves, T. (1995). Human resource strategies and firm performance: What do we know and where do we need to go? International Journal of Human Resource Management, 6(3), 656-670.

Eisenhardt, K., \& Martin, J. (2000). Dynamic capabilities: What are they? Strategic Management Journal, 21(10-11), $1105-1121$.

Fornell, C., \& Larcker, D. F. (1981). Structural equation models with unobservable variables and measurement error: Algebra and statistics. Journal of Marketing Research, 18(3), 382-388.

Galunic, D. C., \& Rodan, S. (1998). Resource recombinations in the firm: Knowledge structures and the potential for Schumpeterian innovation. Strategic Management Journal, 19(12), 1993-1201.

Hair, J. F., Ringle, C. M., \& Sarstedt, M. (2011). PLS-SEM: Indeed a silver bullet. Journal of Marketing Theory and Practice, 19(2), 139-152.

Hair, J. F., Ringle, C. M., \& Sarstedt, M. (2013). A primer on partial least squares structural equation modeling (PLSSEM). Thousand Oaks, CA: SAGE.

Hair, J. F. Jr., Sarstedt, M., Hopkins, L., \& Kuppelwieser, V. G. (2014). Partial least squares structural equation modeling (PLS-SEM): An emerging tool in business research. European Business Review, 26(2), 106-121.

Helfat, C. E., Finkelstein, S., Mitchell, W., Peteraf, M., Singh, H., Teece, D., \& Winter, S. G. (2009). Dynamic capabilities: Understanding strategic change in organizations. Malden, MA: Blackwell Publishing.

Helfat, C. E., \& Martin, J. A. (2015). Dynamic managerial capabilities: Review and assessment of managerial impact on strategic change. Journal of Management, 41(5), 1281-1312.

Helfat, C. E., \& Peteraf, M. A. (2009). Understanding dynamic capabilities: Progress along a developmental path. Strategic Organization, 7(1), 91-102. https://doi.org/10.1177/1476127008100133.

Hsu, L. C., \& Wang, C. H. (2012). Clarifying the effect of intellectual capital on performance: The mediating role of dynamic capability. British Journal of Management, 23(2), 179-205.

Hulland, J. (1999). Use of partial least squares (PLS) in strategic management research: A review of four recent studies. Strategic Management Journal, 20(2), 195-204.

Iansiti, M., \& Clark, K. B. (1994). Integration and dynamic capability: Evidence from product development in automobiles and mainframe computers. Industrial and Corporate Change, 3(3), 557-605.

Karim, S., \& Capron, L. (2016). Adding, redeploying, recombining and divesting resources and business units. Strategic Management Journal, 37(13), 54-62.

Kirca, A. H., Satish, J., \& Bearden, W. O. (2005). Market orientation: A meta-analytic review and assessment of its antecedents and impact on performance. Journal of Marketing, 69(2), 24-41.

Kotha, R., Zheng, Y. F., \& George, G. (2011). Entry into new niches: The effects of firm age and the expansion of technological capabilities on innovative output and impact. Strategic Management Journal, 32(9), 1011-1024.

Koza, M. P., Tallman, S., \& Ataay, A. (2011). The strategic assembly of global firms: A microstructural analysis of local learning and global adaptation. Global Strategy Journal, 1(1-2), 27-46. 
Kraatz, M. S., \& Zajac, E. J. (2001). How organizational resources affect strategic change and performance in turbulent environments: Theory and evidence. Organization Science, 12(5), 632-657.

Laursen, K., \& Salter, A. (2006). Open for innovation: The role of openness in explaining innovation performance among UK manufacturing firms. Strategic Management Journal, 27(2), 131-150.

Liao, J. J., Kickul, J. R., \& Ma, H. (2009). Organizational dynamic capability and innovation: An empirical examination of internet firms. Journal of Small Business Management, 47(3), 263-286.

Marsh, H. W., Hau, K.-T., Balla, J. R., \& Grayson, D. (1998). Is more ever too much? The number of indicators per factor in confirmatory factor analysis. Multivariate Behavioral Research, 33(2), 181-220.

Marsh, S. J., \& Stock, G. N. (2006). Creating dynamic capability: The role of intertemporal integration, knowledge retention, and interpretation. Journal of Product Innovation Management, 23(5), 422-436.

Nelson, R. R., \& Winter, S. G. (1982). An evolutionary theory of economic change. Cambridge, MA: Harvard Business School Press.

Nonaka, I. (1994). A dynamic theory of organizational knowledge creation. Organization Science, 5(1), 14-37.

O'Reilly, C. A., \& Tushman, M. L. (2008). Ambidexterity as a dynamic capability: Resolving the innovator's dilemma. Research in Organizational Behavior, 28, 185-206.

Peng, M. W. (2003). Institutional transitions and strategic choices. Academy of Management Review, 28(2), 275-296.

Peteraf, M., Di Stefano, G., \& Verona, G. (2013). The elephant in the room of dynamic capabilities: Bringing two diverging conversations together. Strategic Management Journal, 34(12), 1389-1410.

Podsakoff, P. M., MacKenzie, S. B., Lee, J.-Y., \& Podsakoff, N. P. (2003). Common method biases in behavioral research: A critical review of the literature and recommended remedies. Journal of Applied Psychology, 88(5), 879-903.

Podsakoff, P. M., \& Organ, D. W. (1986). Self-reports in organizational research: Problems and prospects. Journal of Management, 12(4), 531-544.

Prencipe, A. (1997). Technological competencies and product's evolutionary dynamics - a case study from the aero-engine industry. Research Policy, 25(8), 1261-1276.

Prieto, I. M., Revilla, E., \& Rodríguez-Prado, B. (2009). Building dynamic capabilities in product development: How do contextual antecedents matter? Scandinavian Journal of Management, 25(3), 313-326.

Protogerou, A., Caloghirou, Y., \& Lioukas, S. (2012). Dynamic capabilities and their indirect impact on firm performance. Industrial and Corporate Change, 21(3), 615-647.

Qian, C., Wang, H., Geng, X., \& Yu, Y. (2017). Rent appropriation of knowledge-based assets and firm performance when institutions are weak: A study of Chinese publicly listed firms. Strategic Management Journal, 38(4), 892-911.

Rosenkopf, L., \& Nerkar, A. (2001). Beyond local search: Boundary-spanning, exploration, and impact in the optical disk industry. Strategic Management Journal, 22(4), 287-306.

Sampson, R. C. (2005). Experience effects and collaborative returns in R\&D alliances. Strategic Management Journal, 26(11), 1009-1031.

Schilke, O. (2014). On the contingent value of dynamic capabilities for competitive advantage: The nonlinear moderating effect of environmental dynamism. Strategic Management Journal, 35(2), 179-203.

Schumpeter, J.A. (1942). Capitalism, socialism, and democracy. New York, NY: Harper \& Brothers.

Stadler, C., Helfat, C. E., \& Verona, G. (2013). The impact of dynamic capabilities on resource access and development. Organization Science, 24(6), 1782-1804.

Subramaniam, M., \& Youndt, M. A. (2005). The influence of intellectual capital on the types of innovative capabilities. Academy of Management Journal, 48(3), 450-463.

Tan, J. (2002). Impact of ownership type on environment-strategy linkage and performance: Evidence from a transitional economy. Journal of Management Studies, 39(3), 333-354.

Tang, Z., \& Tang, J. (2012). Entrepreneurial orientation and SME performance in China's changing environment: The moderating effects of strategies. Asia Pacific Journal of Management, 29(2), 409-431.

Teece, D. J. (2000). Strategies for managing knowledge assets: The role of firm structure and industrial context. Long Range Planning, 33(1), 35-54.

Teece, D. J. (2007). Explicating dynamic capabilities: The nature and microfoundations of (sustainable) enterprise performance. Strategic Management Journal, 28(13), 1319-1350.

Teece, D. J. (2014a). A dynamic capabilities-based entrepreneurial theory of the multinational enterprise. Journal of International Business Studies, 45(1), 8-37. 
Teece, D. J. (2014b). The foundations of enterprise performance: Dynamic and ordinary capabilities in an (economic) theory of firms. The Academy of Management Perspectives, 28(4), 328-352.

Teece, D. J., Pisano, G., \& Shuen, A. (1997). Dynamic capabilities and strategic management. Strategic Management Journal, 18(7), 509-533.

Todorova, G., \& Durisin, B. (2007). Absorptive capacity: Valuing a reconceptualization. Academy of Management Review, 32(3), 774-786.

Utterback, J. M. (1986). Innovation and corporate strategy. International Journal of Technology Management, 1(1-2), 119-132.

Wang, C. L., \& Ahmed, P. K. (2007). Dynamic capabilities: A review and research agenda. International Journal of Management Reviews, 9(1), 31-51.

Wang, H. C., He, J., \& Mahoney, J. T. (2009). Firm-specific knowledge resources and competitive advantage: The roles of economic- and relationship-based employee governance mechanisms. Strategic Management Journal, 30(12), $1265-1285$.

Wilden, R., Gudergan, S. P., Nielsen, B. B., \& Lings, I. (2013). Dynamic capabilities and performance: Strategy, structure and environment. Long Range Planning, 46(1-2), 72-96.

Winter, S. G. (2003). Understanding dynamic capabilities. Strategic Management Journal, 24(10), 991-995.

$\mathrm{Xu}, \mathrm{D}$., Lu, J. W., \& Gu, Q. (2014). Organizational forms and multi-population dynamics. Administrative Science Quarterly, 59(3), 517-547.

Yam, R. C. M., Lo, W., Tang, E. P. Y., \& Lau, A. K. W. (2011). Analysis of sources of innovation, technological innovation capabilities, and performance: An empirical study of Hong Kong manufacturing industries. Research Policy, 40(3), 391-402.

Young, M. N., Tsai, T., Wang, X., Liu, S., \& Ahlstrom, D. (2014). Strategy in emerging economies and the theory of the firm. Asia Pacific Journal of Management, 31(2), 331-354.

Zahra, S. A., \& Bogner, W. C. (2000). Technology strategy and software new ventures' performance: Exploring the moderating effect of the competitive environment. Journal of Business Venturing, 15(2), 135-173.

Zahra, S. A., \& George, G. (2002). Absorptive capacity: A review, reconceptualization, and extension. Academy of Management Review, 27(2), 185-203.

Zahra, S. A., Sapienza, H. J., \& Davidsson, P. (2006). Entrepreneurship and dynamic capabilities: A review, model and research agenda. Journal of Management Studies, 43(4), 917-955.

Zhang, Y., Li, H., Li, Y., \& Zhou, L. A. (2010). FDI spillovers in an emerging market: The role of foreign firms' country origin diversity and domestic firms' absorptive capacity. Strategic Management Journal, 31(9), 969-989.

Zhao, X., Lynch, J. G., \& Chen, Q. (2010). Reconsidering Baron and Kenny: Myths and truths about mediation analysis. Journal of Consumer Research, 37(2), 197-206.

Zhou, K. Z., \& Li, C. B. (2012). How knowledge affects radical innovation: Knowledge base, market knowledge acquisition, and internal knowledge sharing. Strategic Management Journal, 33(9), 1090-1102.

Zhou, K. Z., Yim, C. K., \& Tse, D. K. (2005). The effects of strategic orientations on technology- and market-based breakthrough innovations. Journal of Marketing, 69(2), 42-60.

Zott, C. (2003). Dynamic capabilities and the emergence of intraindustry differential firm performance: Insights from a simulation study. Strategic Management Journal, 24(2), 97-125. 